\title{
MET immunochemistry: a reliable screening tool for MET exon 14 skipping mutations in non-small cell lung cancer?
}

\author{
Melinda A. Pruis ${ }^{1,2}$, Jan H. von der Thüsen ${ }^{3}$, Hendrikus Jan Dubbink ${ }^{3}$ \\ ${ }^{1}$ Department of Pulmonary Diseases, ${ }^{2}$ Department of Medical Oncology, ${ }^{3}$ Department of Pathology, Erasmus MC Cancer Institute, Rotterdam, the \\ Netherlands \\ Correspondence to: Dr. Hendrikus Jan Dubbink. Department of Pathology, Erasmus MC Cancer Institute, Dr. Molewaterplein 40, 3015 GD \\ Rotterdam, The Netherlands. Email: h.dubbink@erasmusmc.nl. \\ Comment on: Baldacci S, Figeac M, Antoine M, et al. High MET Overexpression Does Not Predict the presence of MET exon 14 Splice Mutations in \\ NSCLC: Results From the IFCT PREDICT.amm study. J Thorac Oncol 2020;15:120-4.
}

Submitted May 06, 2020. Accepted for publication May 09, 2020.

doi: $10.21037 /$ atm-20-3763

View this article at: http://dx.doi.org/10.21037/atm-20-3763

Worldwide, lung cancer kills more people than any other cancer (1). The median survival of patients with advanced lung cancer is approximately 9 months $(2,3)$. However, the discovery of actionable driver mutations and subsequent development of targeted therapy has dramatically improved the survival of a subset of lung cancer patients $(4,5)$. Amongst the newer driver mutations in non-small cell lung cancer (NSCLC) is the MET exon 14 skipping mutation, which leads to a more stable active MET receptor and affects about $2-5 \%$ of non-squamous NSCLC $(6,7)$. Patients with this mutation are generally older and have a smoking history (7). No significant gender predilection has been determined. Especially for this elderly population, it is compelling to consider targeted anti-cancer therapy rather than intense chemotherapy regimens, and in several studies targeting MET exon 14 skipping mutations showed promising results (7-10). The surge of development of MET inhibitors has led to a need for reliable and feasible diagnostic tests and predictive biomarkers.

For detection of MET exon 14 skipping mutations different strategies can be applied. Tumor RNA analysis is potentially the most accurate, because it allows for detection of all resulting MET exon 13-15 fusions independent of the underlying DNA mutation (11). However, acquiring sufficient tumor tissue for RNA analysis is often difficult (11). An alternative is tumor DNA-based analysis, which detects the specific genomic alterations leading to exon 14 skipping. Exon 14 skipping can, however, be caused by a variety of mutations, including point mutations or small deletions involving the corresponding splice sites, large intron-exon or exon-intron spanning mutations and large, entirely intronic, deletions present in the adjacent introns, so a dedicated DNA panel is required to cover all these mutations (12). While DNA testing is highly specific and sensitive, it is relatively expensive with a limited availability in routine diagnostic laboratories (7). Also, large deletions can easily be missed by DNA-based next generation sequencing (NGS), but alternatively might be detected by fragment length analysis (FLA) $(12,13)$.

In the brief report of Baldacci et al. they investigated if MET overexpression is predictive for the presence of MET exon 14 skipping mutations (14). This could be relevant as a screening tool for MET exon 14 skipping mutations. For their research, they used the IFCT-PREDICT.amm cohort, which consists of 843 patients with treatmentnaive advanced NSCLC, who were prospectively observed in a longitudinal cohort study from 2013-2014. For the analysis, 91 patients with a high MET overexpression (MET 3+ immunoscore) were included. MET exon 14 skipping mutations were investigated by combining DNAbased NGS and FLA as described by Descarpentries (13). Two out of 91 patients in the MET immunohistochemistry (IHC) high group had a MET exon 14 skipping mutation. In addition, they analyzed a group of 131 patients with no or low MET expression. In this group, also 2 patients had a MET exon 14 skipping mutation. They conclude that the rate of MET exon 14 skipping mutations is similar in patients with no or low $v$ s. high MET expression. 
Combined mutation and gene copy number analysis in the high MET overexpression patients demonstrate that only $10 \%$ of these patients showed a MET exon 14 mutation or a MET gene amplification. The majority of high MET overexpression seems therefore not be directly linked to a genetic aberration of the MET gene. Also, their results indicate that high MET overexpression is not mutually exclusive with other oncogenic driver mutations, like activating EGFR or KRAS mutations.

As the detection of MET exon 14 skipping mutations poses difficulties, the researchers in this study by Baldacci et al., opt for MET IHC as a screening tool for MET exon 14 skipping mutations (14). They combined NGS with FLA, so probably no MET exon 14 skipping mutations were missed and indeed the prevalence of $2.2 \%$ is in accordance with current literature $(7,14)$. While 2 patients is a small number to base firm conclusions on, Guo et al. performed a similar study in 2019 and they came to the same conclusion as Baldacci et al:: MET IHC is not suitable as a screening tool to detect MET exon 14 skipping mutations (15). In 2018, Lambros et al. also described MET IHC as a very weak tool for screening purposes and they report that MET IHC might even decrease the probability of predicting MET exon 14 skipping mutations in a multiclass model (16). This can be explained by several reasons. First of all, not all MET exon 14 skipping mutations are IHC MET positive, probably due to technical issues with MET IHC assessment, and heterogeneity in scoring systems and interpretation (17). In addition, large validation studies for the Ventana SP44 antibody, which is widely used for measuring MET expression, are lacking and SP44 might be less reliable for detecting MET protein products in reducing conditions (17). Baldacci et al. also suggest that some phenotypical variations of MET exon 14 skipping mutations might not result in MET overexpression $(14,18)$. Secondly, in this study, only $10 \%$ of the lung cancer patients with high MET expression displayed an underlying genetic alteration of MET. This indicates that there might be other causes of MET upregulation, making MET overexpression a very non-specific screening tool for MET gene aberrations (19). Another limitation of MET IHC is that the measured MET expression does not always correlate with p-MET (activated MET receptor) and therefore does not reflect MET activation (20,21). The usefulness of MET IHC in the selection of MET amplification is also dubious. Many studies do find a correlation between MET amplification and MET IHC positivity, as is to be expected (22-25).
More recently, however, Guo et al. reported no association between MET IHC positivity and MET amplification measured by NGS or fluorescence in situ hybridization (FISH) and also Schuler et al. showed no correlation between MET amplification by FISH and MET expression by $\operatorname{IHC}(15,26)$.

In addition, several trials have investigated the possibility of MET IHC as a predictive biomarker for targeted MET therapy $(27,28)$. Unfortunately, the disappointing results of these studies unambiguously demonstrated that MET IHC is a weak biomarker for MET inhibitors (26-28).

Based on these results, we believe that, currently, there is no place for MET IHC as screening tool or as biomarker for MET exon 14 skipping mutations. Therefore, detection of MET exon 14 skipping mutations remains dependent on RNA and DNA analysis.

\section{Acknowledgments}

Funding: None.

\section{Footnote}

Provenance and Peer Review: This article was commissioned by the editorial office, Annals of Translational Medicine. The article did not undergo external peer review.

Conflicts of Interest: All authors have completed the ICMJE uniform disclosure form (available at http://dx.doi. org/10.21037/atm-20-3763). HJD reports grants, personal fees and non-financial support from AstraZeneca, personal fees from AbbVie, personal fees from Janssen, personal fees from Pfizer, personal fees from Lilly, personal fees from PGDx, personal fees from MSD, outside the submitted work. The other authors have no other conflicts of interest to declare.

Ethical Statement: The authors are accountable for all aspects of the work in ensuring that questions related to the accuracy or integrity of any part of the work are appropriately investigated and resolved.

Open Access Statement: This is an Open Access article distributed in accordance with the Creative Commons Attribution-NonCommercial-NoDerivs 4.0 International License (CC BY-NC-ND 4.0), which permits the noncommercial replication and distribution of the article with the strict proviso that no changes or edits are made and the 
original work is properly cited (including links to both the formal publication through the relevant DOI and the license). See: https://creativecommons.org/licenses/by-nc-nd/4.0/.

\section{References}

1. Barta JA, Powell CA, Wisnivesky JP. Global Epidemiology of Lung Cancer. Ann Glob Health 2019;85:8.

2. Sandler A, Gray R, Perry MC, et al. Paclitaxel-carboplatin alone or with bevacizumab for non-small-cell lung cancer. N Engl J Med 2006;355:2542-50.

3. Schiller JH, Harrington D, Belani CP, et al. Comparison of four chemotherapy regimens for advanced non-smallcell lung cancer. N Engl J Med 2002;346:92-8.

4. Sequist LV, Lynch TJ. EGFR Tyrosine Kinase Inhibitors in Lung Cancer: An Evolving Story. Ann Rev Med 2008;59:429-42.

5. Shaw AT, Kim DW, Nakagawa K, et al. Crizotinib versus chemotherapy in advanced ALK-positive lung cancer. N Engl J Med 2013;368:2385-94.

6. Cancer Genome Atlas Research N. Comprehensive molecular profiling of lung adenocarcinoma. Nature 2014;511:543-50.

7. Pruis MA, Geurts-Giele WRR, von der TJH, et al. Highly accurate DNA-based detection and treatment results of MET exon 14 skipping mutations in lung cancer. Lung Cancer 2020;140:46-54.

8. Drilon A, Clark JW, Weiss J, et al. Antitumor activity of crizotinib in lung cancers harboring a MET exon 14 alteration. Nat Med 2020;26:47-51.

9. Wolf J, Seto T, Han J, et al. Capmatinib (INC280) in MET $\Delta$ ex14-mutated advanced non-small cell lung cancer (NSCLC): Efficacy data from the phase II GEOMETRY mono-1 study. J Clin Oncol 2019;37.

10. Paul KP, Remi V, Alexis BC, et al. Phase II study of tepotinib in NSCLC patients with METex14 mutations. J Clin Oncol 2019;37:9005.

11. Davies KD, Lomboy A, Lawrence CA, et al. DNA-Based versus RNA-Based Detection of MET Exon 14 Skipping Events in Lung Cancer. J Thorac Oncol 2019;14:737-41.

12. Poirot B, Doucet L, Benhenda S, et al. MET Exon 14 Alterations and New Resistance Mutations to Tyrosine Kinase Inhibitors: Risk of Inadequate Detection with Current Amplicon-Based NGS Panels. J Thorac Oncol 2017;12:1582-7.

13. Descarpentries C, Lepretre F, Escande F, et al. Optimization of Routine Testing for MET Exon 14 Splice Site Mutations in NSCLC Patients. J Thorac Oncol
2018;13:1873-83.

14. Baldacci S, Figeac M, Antoine M, et al. High MET Overexpression Does Not Predict the presence of MET exon 14 Splice Mutations in NSCLC: Results From the IFCT PREDICT.amm study. J Thorac Oncol 2020;15:120-4.

15. Guo R, Berry LD, Aisner DL, et al. MET IHC Is a Poor Screen for MET Amplification or MET Exon 14 Mutations in Lung Adenocarcinomas: Data from a Tri-Institutional Cohort of the Lung Cancer Mutation Consortium. J Thorac Oncol 2019;14:1666-71.

16. Lambros L, Uguen A. MET Immunohistochemistry Should Be Avoided in Selecting Non-small-cell Lung Cancers Requiring MET Exon 14 Skipping Mutation Analysis. Clin Lung Cancer 2019;20:e418-20.

17. De Herdt MJ, Willems SM, van der Steen B, et al. Absent and abundant MET immunoreactivity is associated with poor prognosis of patients with oral and oropharyngeal squamous cell carcinoma. Oncotarget 2016;7:13167-81.

18. Cortot AB, Kherrouche Z, Descarpentries C, et al. Exon 14 Deleted MET Receptor as a New Biomarker and Target in Cancers. J Natl Cancer Inst 2017;109.

19. Sacco JJ, Clague MJ. Dysregulation of the Met pathway in non-small cell lung cancer: implications for drug targeting and resistance. Transl Lung Cancer Res 2015;4:242-52.

20. Tsuta K, Kozu Y, Mimae T, et al. c-MET/phospho-MET protein expression and MET gene copy number in nonsmall cell lung carcinomas. J Thorac Oncol 2012;7:331-9.

21. Onitsuka T, Uramoto H, Ono K, et al. Comprehensive molecular analyses of lung adenocarcinoma with regard to the epidermal growth factor receptor, K-ras, MET, and hepatocyte growth factor status. J Thorac Oncol 2010;5:591-6.

22. Ferlay J, Soerjomataram I, Dikshit R, et al. Cancer incidence and mortality worldwide: sources, methods and major patterns in GLOBOCAN 2012. Int $\mathrm{J}$ Cancer 2015;136:E359-86.

23. Dziadziuszko R, Wynes MW, Singh S, et al. Correlation between MET gene copy number by silver in situ hybridization and protein expression by immunohistochemistry in non-small cell lung cancer. J Thorac Oncol 2012;7:340-7.

24. Park S, Koh J, Kim DW, et al. MET amplification, protein expression, and mutations in pulmonary adenocarcinoma. Lung Cancer 2015;90:381-7.

25. Bubendorf L, Dafni U, Schöbel M, et al. Prevalence and clinical association of MET gene overexpression and amplification in patients with NSCLC: Results from 
the European Thoracic Oncology Platform (ETOP)

Lungscape project. Lung Cancer 2017;111:143-9.

26. Schuler M, Berardi R, Lim WT, et al. Molecular correlates of response to capmatinib in advanced non-small-cell lung cancer: clinical and biomarker results from a Phase I trial. Ann Oncol 2020. [Epub ahead of print].

27. Spigel DR, Edelman MJ, O'Byrne K, et al. Results From the Phase III Randomized Trial of Onartuzumab Plus Erlotinib Versus Erlotinib in Previously Treated Stage IIIB

Cite this article as: Pruis MA, von der Thüsen JH, Dubbink HJ. MET immunochemistry: a reliable screening tool for MET exon 14 skipping mutations in non-small cell lung cancer? Ann Transl Med 2020;8(22):1538. doi: 10.21037/atm20-3763 or IV Non-Small-Cell Lung Cancer: METLung. J Clin Oncol 2017;35:412-20.

28. Neal JW, Dahlberg SE, Wakelee HA, et al. Erlotinib, cabozantinib, or erlotinib plus cabozantinib as secondline or third-line treatment of patients with EGFR wildtype advanced non-small-cell lung cancer (ECOG-ACRIN 1512): a randomised, controlled, open-label, multicentre, phase 2 trial. Lancet Oncol 2016;17:1661-71. 